\title{
Evaluation of entomopathogenic fungus Verticillium lecanii (Zimmermann) Vieges and the predator Chrysoperla carnea (Stephens) against cowpea aphid, Aphis craccivora (Koch) on faba bean in EGYPT
}

\author{
Hany A. S. Abd El-Gawad and Atef M.M. Sayed \\ Biological Control Research Dept., Plant Protection Research Institute, A.R.C., \\ Dokki, Giza, Egypt.
}

\begin{abstract}
Three tested treatments of the entomopathogenic fungus Verticillium lecanii (Zimmermann) Vieges, the predator Chrysoperla carnea (Stephens) and V. lecanii followed by release of $C$. carnea in faba bean field for controlling cowpea aphid, Aphis craccivora (Koch) compared with control were conducted. The first treatment was $V$. lecanii repeated 4 times at 15 -days intervals at the rate of $10^{8} \mathrm{spores} / \mathrm{ml}$. The second was $C$. carnea at the same intervals at the rate of 12,000 predator [larvae (L2)]/feddan/releases. The third was $V$. lecanii applied 2 times at 15-days intervals at the same rate followed by release of $C$. carnea 2 times at 15-days intervals at the same rate. Treatments were conducted during 2006-2007 and 2007-2008 at a location in Ismailia Governorate. These treatments indicated the potential use of these treatments to control A. craccivora on faba bean. Reduction in A. craccivora population and subsequent yields were significant between treatments. Highest reduction and yield gain was observed when fungus $V$. lecanii was applied.
\end{abstract}

Keywords: Entomopathogenic, Verticillium lecanii, Chrysoperla carnea, Aphis craccivora

\section{INTRODUCTION}

Faba bean is one of the most economic winter crops in Egypt. Extensive efforts are yearly adopted to achieve both high quality and quantity of yield of this legume crop. This crop locally consumed possessing high nutrients value of proteins and carbohydrates (Bahy El-Din, 2006).

Aphids (Homoptera: Aphididae) are serious insect pests attacking nearly all plants including field crops. They feed by sucking plant sap causing leaf curl, wilting, stunting in shoot growth, reducing final yield as well as a general decline in plant vigor. Some aphids are also vectors of plant diseases. The cowpea aphid, Aphis craccivora (Koch) is a good example of these aphids causing serious problems to legumes (Abdel-Rahman et al., 2007).

The fungus Verticillium lecanii (Zimmermann) Vieges has been considered as an effective biocontrol agent, against aphid pests in general. However, the fungal activity, as a biocide, is a function of its virulence under field conditions. The virulence of such a pathogen is probably associated with certain strains or isolates of the fungus, as well as its infection mechanism. The environmental conditions, particularly humidity, can also influence the fungal activity under field conditions. High humidity is essential for infection to initiate and may even be required for the development of infection on the target host (Sewify, 1989).

The green lacewings, Chrysoperla carnea (Stephens) is voracious predators of a wide variety of soft-bodied arthropods including aphids, scales, mealybug, caterpillars, leafhoppers, psyllids, white flies, thrips, insect eggs, spiders, mites and others (Canard and Principi, 1984). Biological control by the use of C. carnea has 
gained importance in pest management because of its ability to control a host range soft bodied plant pests, having higher searching ability, vast geographical distribution, ease of mass production, wide adaptability in field than other predators and its tolerance to the wide ranges of ecological factors (Saminathan et al., 1999 and Tauber et al., 2000).

The present study amid at the releasing of $C$. carnea as a predator and the fungus $V$. 1ecanii for controlling A. craccivora during growing seasons of 2006/2007 and 2007/ 2008 at a location in Ismailia Governorate.

\section{MATERIAL AND METHODS}

Rearing of insects: The angoumois grain moth, Sitotroga cerealella (Olivier) was cultured in the laboratory as prey for rearing C. carnea according to the method described by Abd El-Gawad and Abd Al-Aziz (2005).

The predator C. carnea was cultured in the laboratory according to the method described by (Ali, 1998).

Preparation of fungus inoculums: Entomopathogenic fungus $V$. lecanii (originally isolated by Abd El-Gawad, 2000) was used. Conidiospores suspension was sprayed on A. craccivora and incubated at $25{ }^{\circ} \mathrm{C}$ and $65 \pm 5 \%$ R.H. Following the host death and sporulation, conidiospores were harvested from cadavers and transferred to Petri dishes containing potato-dextrose agar media (PDA). Isolated fungus was grown using autoclaved PDA media enriched with $1 \%$ peptone, $4 \%$ glucose, $2 \%$ yeast and 5 gm streptomycin (Rombach et al., 1988).

The cultures were incubated at $25^{\circ} \mathrm{C}$ for 10 days. Cultures with fully developed conidiospores were washed by sterilized distilled water mixed with $0.05 \%$ Tween 80 to obtain the stock spore suspension. Spores suspended in sterilized water were counted with a haemocytometer.

Production of conidiospores for field application: Fungal conidia ( $V$. lecanii) was produced on a barley substrate composed of $50 \mathrm{gm}$ of barley, $35 \mathrm{ml}$ distilled water and $2 \mathrm{ml}$ pressed sun flower oil. The barley mixed with water and oil was autoclaved in Erlenmeyer flasks $(300 \mathrm{ml})$ for $20 \mathrm{~min}$ at $121{ }^{\circ} \mathrm{C}$. Immediately after the lumps of grain were destroyed by shaking the flasks vigorously, the flasks were cooled to room temperature and inoculated with $1 \mathrm{ml}$ of conidia suspension with $10^{6} \mathrm{spores} / \mathrm{ml}$, then incubated for 2-3 weeks in the dark at $25 \pm 1{ }^{\circ} \mathrm{C}$. The conidia were harvested by suspending them in $50 \mathrm{ml}$ of $0.05 \%$ Tween 80 . The suspension was filtrated through a double layer of muslin and the desired concentration for field application was obtained by the addition of sterile distilled water. Total spores were counted before application in the field using a haemocytometer.

Field studies: An area of about half feddan (i.e. $2100 \mathrm{~m}^{2}$ ) cultivated with faba bean was chosen at Ismailia Governorate. This area was divided separately into 3 treatments and control (C.). Faba bean was sown on November, $30^{\text {th }}$ and $29^{\text {th }}$ during 2006 and 2007 seasons, respectively. All plots received the normally recommended agricultural practices. Experimental treatments started on January, $4^{\text {th }}$ and $5^{\text {th }}$ during 2006/2007 and 2007/2008, respectively. The entomopathogenic fungus $V$. lecanii (F) was sprayed 4 times at 15 -days intervals at a rate of $10^{8}$ spores $/ \mathrm{ml}$. C. carnea $(\mathrm{P})$ was released 4 times at 15-days intervals by a rate of 12,000 predator [larvae (L2)]/feddan/releases. V. lecanii was applied 2 times at the same intervals and rate followed by $C$. carnea release 2 times at the same intervals and rate (FP) for controlling the cowpea aphid, A. craccivora. Sampling started on January, $11^{\text {th }}$ and $12^{\text {th }}$ and continued weekly until April, $26^{\text {th }}$ and $26^{\text {th }}$ during 2007 and 2008 seasons, 
respectively. The efficacy of different treatments was measured as the number of survived individuals for the cowpea aphid, A. craccivora on 10 plants.

\section{Statistical Analysis:}

The formula of Henderson and Tilton (1955) was used to calculate the reduction rate among populations of the targeted the cowpea aphid, A. craccivora in the field after application with the three tested treatments. Obtained data were subjected to analysis of variance (ANOVA) and the means were compared by L.S.D. test at 0.05 level, using SAS (Anonymous, 1988).

Yield Assessments: Yield was evaluated at the end of the experiment for each treatment. Data are presented as estimated weight $\mathrm{Kg} /$ feddan.

\section{RESULTS AND DISCUSSION}

\section{Field studies}

\section{1- Application of $V$. 1ecanii and releasing of $C$. carnea as a predator against $A$.} craccivora in faba bean field:

Results concerning the effect of tested treatments on A. craccivora and their percentage reduction are presented herein.

Obtained results revealed that the numbers of $A$. craccivora adults and nymphs on faba bean plants were obviously reduced in the various treatments compared with the control. The overall means of A. craccivora were $(69.19,82,102.06 \& 158.88)$ and $(81.88,95.19,116.13 \& 176.13)$ on faba bean plants, respectively during 20062008 for the three treatments and control, respectively (Figs.1 and 2).

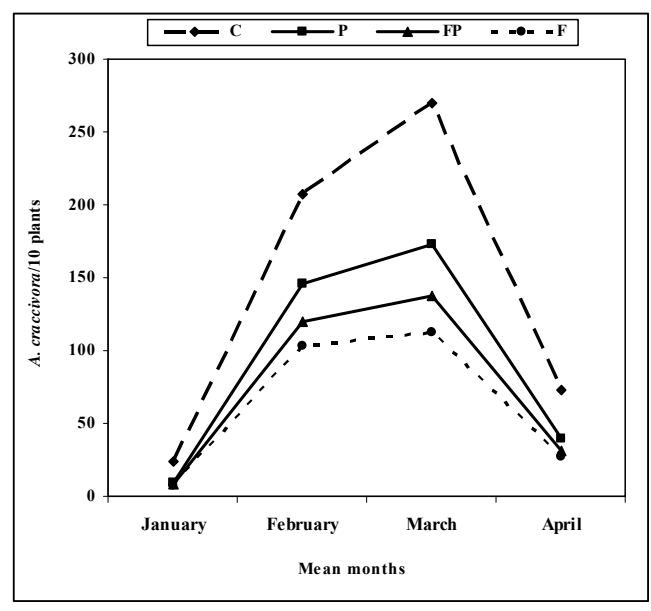

Fig.1: Mean numbers of $A$. craccivor as result of treating faba bean plants with the fungus $V$. 1ecanii (F), V. 1ecanii followed by C. Carnea (FP) and releasing of $C$. Carnea as a predator $(\mathrm{P})$ compared with control (C) in Ismailia Governorate during 2006-2007 seasons.

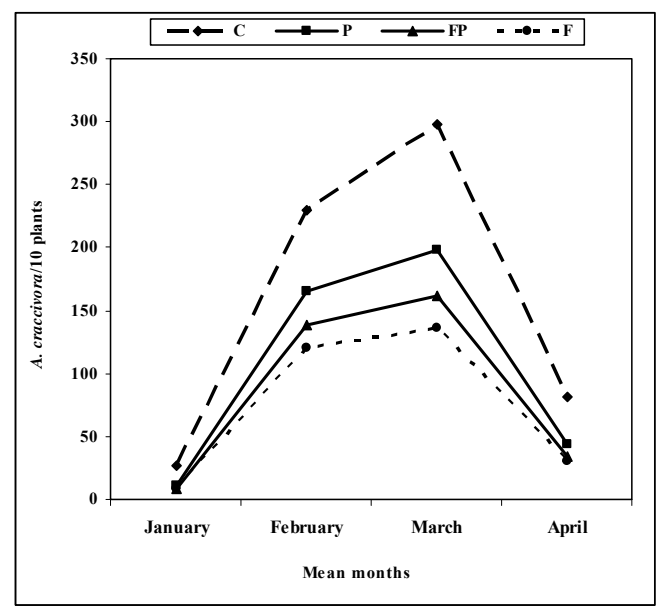

Fig. 2: Mean numbers of $A$. craccivor as result of treating faba bean plants with the fungus $V$. 1ecanii $(\mathrm{F}), \mathrm{V}$. 1ecanii followed by C. Carnea (FP) and releasing of $C$. Carnea as a predator (P) compared with control (C) in Ismailia Governorate during 20072008 seasons.

Statistical analysis of the cowpea aphid, A. craccivora population for year 2006-2008 showed significant differences between the three tested treatments compared with the control. The obtained values for 2006-2007 for A. craccivora were $\mathrm{F}=28.87, \mathrm{P}=0.0001$ and L.S.D. $=21.00$. The relative values during 2007- 2008 for $A$. craccivora were $\mathrm{F}=31.15, \mathrm{P}=0.0001$ and L.S.D. $=21.26$. 
Average reduction of $A$. craccivora is illustrated at Fig. 3. The obtained reduction was $64.89,57.22$ and $47.52 \%$ due to F, FP and P, respectively during 20062007. The relative results for the three treatments had the same trend (i.e. $62.44,55.43$ and $45.60 \%$, during 2007-2008, respectively).

Statistical analysis for 2006-2007 and 2007-2008 reduction results showed significant differences between the three tested treatments. Obtained results were $\mathrm{F}=$ 22.03, $\mathrm{P}=0.0001$ and L.S.D. $=5.36$ for $2006-2007$ and $\mathrm{F}=20.07, \mathrm{P}=0.0001$ and L.S.D. $=5.45$ for $2007-2008$.

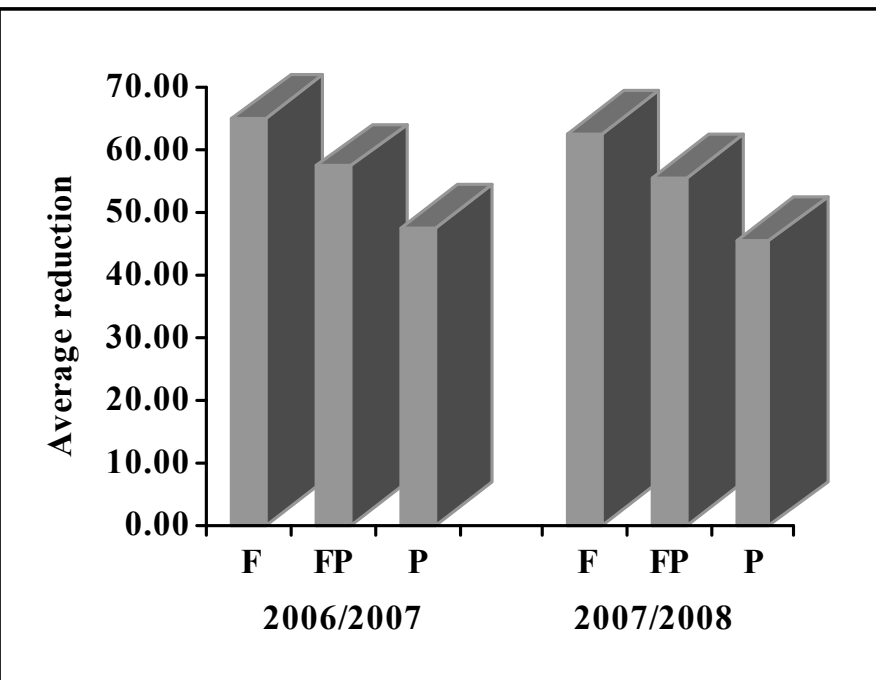

Fig.3: Average reduction of $A$. craccivor as result of treating faba bean plants with the fungus V. 1ecanii (F), V. lecanii followed by C. Carnea (FP) and releasing of C. Carnea as a predator (P) in Ismailia Governorate during 2006-2007 and 2007-2008 seasons.

\section{2- The yield in the experimental field:}

Results of obtained yields are illustrated in Fig. 4. Results revealed that yield was affected by the tested treatments. Applying of fungus V.1ecanii (F) gave the highest yield followed by $V$. 1ecanii followed by releasing of $C$. carnea $(\mathrm{FP})$ and releasing of $C$. carnea $(\mathrm{P})$ only as the least rank during both growing seasons. Increase of yield was in relation to $A$. craccivora population reduction.

In conclusion obtained results revealed that applying fungus $V$. 1ecanii or releasing of $C$. carnea are potential factors for A. craccivora on faba bean under field conditions.

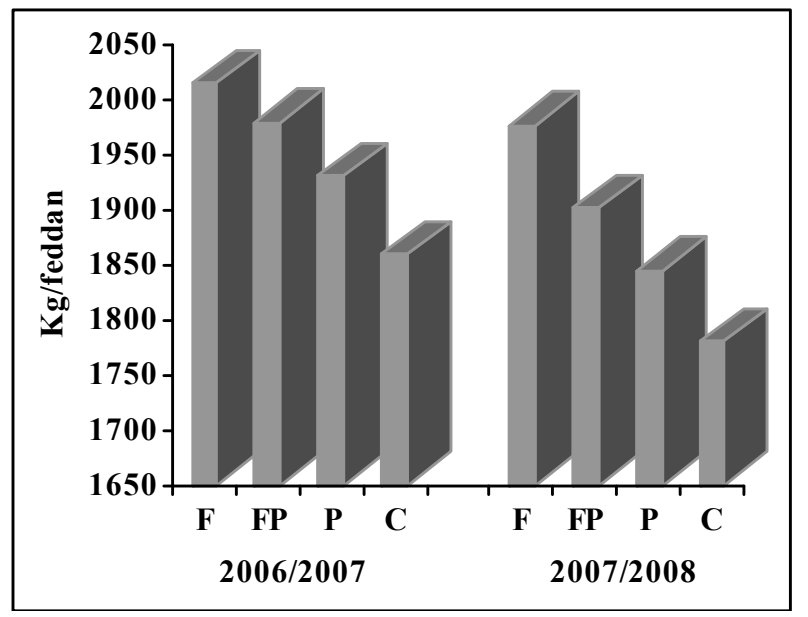

Fig. 4: Yield of faba bean plants (Kg/feddan) in three treatments and a control (C.) in Ismailia Governorate during 2006-2007 and 2007-2008 seasons. 
Obtained results are in agreement with published results in this manner (i.e. Canard and Principi, 1984, Sewify, 1989, Nada, 1999, Mansour, 1999, Saminathan et al., 1999 Tauber et al., 2000, El-Defrawi et al., 2000 and El-Khawas et al., 2004). In general, using of such natural enemies in IPM programmers can be useful with other safe alternative control methods that decrease the application of harmful pesticides.

\section{REFERENCES}

Abd El-Gawad, H.A.S. (2000). Studies on entomopathogenic fungi for controlling certain lepidopterous insects on corn. Unpublished Ph.D. Thesis, Fac. of Agric. Cairo Univ., Egypt 229 pp.

Abd El-Gawad, H.A.S. and Abdel-Aziz A.E. (2005). Use of some biological control elements for controlling the angoumois grain moth, Sitotroga cerealella (Olivier) on wheat and maize grains (Lepidoptera: Gelechiidae). Bull.ent.Soc.Egypt, Econ.Ser. 31:143-155.

Abdel-Rahman G. Abdel-Rahman, El-Bana A. A. and Imam I.I. (2007). Observations on the toxic effects of pirimiphos-methyl on Aphis craccivora (Koch) and its predator Coccinella undecimpunctata L. Proc. $2^{\text {nd }}$ Inter. Conf. Ent. Soc. Egypt, Vol. II, 2007 (299-309).

Ali, K. A. H. (1998): Trials for mass rearing and release of some predaceous insects for controlling the pink spiny Bollworms. Unpublished Ph.D. Thesis, Fac. of Agric., Moshtohor Benha Univ., Egypt, 164 pp.

Anonymous (1988). SAS/STAT User`s Guide, Ver. 6.03. SAS Institute Inc., Cary, North Carolina, $22 \mathrm{pp}$.

Bahy El-Din, I. A. E. (2006). Studies on the biology and feeding capacity of some coccinellid species. Unpublished M.Sc. Thesis, Fac. of Agric., Moshtohor Benha Univ., Egypt.

Canard, M. and Principi M. M. (1984). Life histories and behavior. In: Biology of Chrysopidae (M. Canard, Y. Semeriaand T. R. New (eds.). Dr W. Junk Publishers, The Hague, pp: 57-149.

El-Defrawi, G.M.; Eman A.K.; Marzouk A. and Rizkalla L. (2000). Population dynamics and seasonal distribution of Aphis craccivora (Koch) and associated natural enemies in relation on virus disease incidence in faba bean fields. Egypt. J. Agric. Res., 78(2):627-641.

El-Khawas, M. A. M.; Abulfadl H.A.A. and El-Kady H.A. (2004). Effects of different field treatments on major insect pests attacking faba bean plants. J. Agric. Sci. Mansoura Univ. 29(10): 5925-5938.

Henderson, C. G. and E. W. Tilton (1955). Tests with acaricides against the brown wheat mite. J. Econ. Entomol., 48: 157-161.

Mansour, H.A.M. (1999). Studies in the entomopahogenic fungus Beauveria bassiana as a biological control agent for some economically important insects. Unpublished Ph.D. Thesis, Fac. of Agric. Kafr El-Sheikh, Tanta Univ.

Nada, M. S. (1999). Studies on the utilization of biodiversity of the entomopathogenic fungi against sucking insects abundant in tropical Africa. Unpublished M.Sc. Thesis, Natural Resources Institute of African Research \& Studies, Cairo Univ., Egypt.

Rombach, M. C; Aguda R. M. and Roberts D. W. (1988). Production of Beauveria bassiana in different liquid media and subsequent conidiatioin of dry mycelium. Entomophaga, 33(3): 315-324. 
Saminathan, V. R.; Baskaran R. K. and Mahadeva N. R. (1999). Biology and predatory potential of green lacewing (Chrysoperla carnea) (Neuroptera: Chrysopidae) on different insect hosts. Indian J. Agri. Sci., 69(7): 502-505.

Sewify, G.H. (1989). Evaluation of Verticillium lecanii entomopathogenic fungus and its prospects in controlling aphid pests. Unpublished Ph.D. Thesis, Faculty of Agriculture, Cairo Univercity, $134 \mathrm{pp}$.

Tauber, M. J.; Tauber C. A.; Daane K. M. and Hagen K. S. (2000). Commercialization of predators: recent lessons from green lacewings (Neuroptera: Chrysopidae: Chrysoperla). Am. Entomol., 46: 26-38.

\section{ARABIC SUMMARY}

تقييم الفطر Verticillium lecanii والمفترس Chrysoperla carnea لمكافحة من الفول على الفول البلاى فى مصر

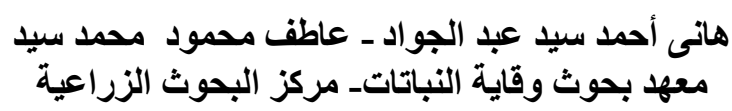

تم تقييم الفطر Verticillium lecanii و والمفترس Chrysoperla carnea لمكافحة من الفول على الاقلى

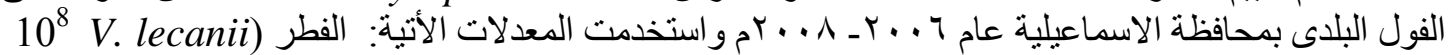

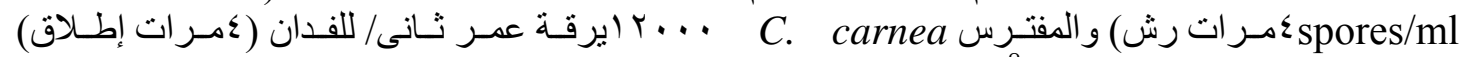

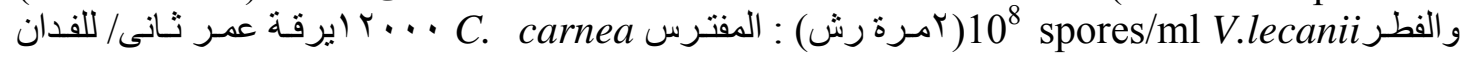

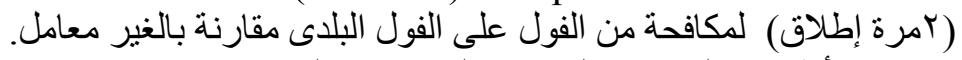

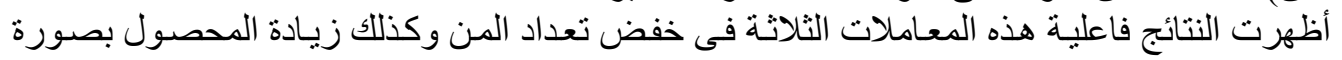

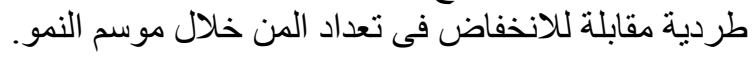

